\section{Susceptibility of American, European, and Interspecific Hybrid Grape Cultivars to the Fungus Septoria ampelina}

\author{
James K. Mitchell ${ }^{1}$ \\ Department of Biology, Ball State University, Muncie, IN 47306 \\ W. Keith Patterson ${ }^{2}$ \\ Department of Horticulture and Forestry, University of Arkansas, Fayetteville, \\ AR 72701
}

\section{Robert H. Ford ${ }^{1}$ \\ Department of Biology, Ball State University, Muncie, IN 47306}

Additional index words. septoria leaf spot, Vitis, table grape, grapevine, plant diseasefungal

Abstract. European Vitis vinifera L. (four cultivars); interspecific hybrid (seven cultivars); and American V. aestivalis Michx. (one cultivar), V. labrusca L. (three cultivars), and $V$. rotundifolia Michx. (two cultivars) grapevines were tested for susceptibility to septoria leaf spot disease. $V$. rotundifolia cultivars Cowart and Fry exhibited hypersensitive-type resistance. All other American, European, and hybrid cultivars tested were susceptible with varying levels of disease severity. Cultivars with little (e.g., interspecific hybrid) or no (e.g., European) $V$. labrusca $\mathrm{L}$. heritage were more susceptible to septoria leaf spot than American $V$. labrusca cultivars.

Septoria leaf spot (also called mélanose), which is caused by the fungus Septoria ampelina Berk. \& Curt., is found infrequently in the eastern United States from New York to Florida and in the midwestem United States from Wisconsin to Texas (McGrew and Pollack, 1988). Very little information exists on the pathogenicity of this fungus. TeterevnikovaBabayan (1977) proposed a key to differentiate seven Septoria spp. found on American grapevines, including Septoria ampelina and S. melanosa Rostr. S. ampelina is the presently accepted species found infecting grapes (McGrew -and Pollack, 1988). Boubals and Mur (1983) isolated S. ampelina from leaves of American grape rootstock 110R (Vitis rupestris Scheele $\times V$. berlandieri Planch.) and SO4 (V. riparia Michx. $\times V$. berlandieri Planch.). The fungus infected American Vitis spp., whereas European $V$. vinifera L. cultivars were immune. No information on susceptibility of interspecific hybrid cultivars was given.

During 1991 and 1992, septoria leaf spot was diagnosed as causing substantial defoliation of American V. labrusca L. CV. Concord grapevines in several vineyards in northwestern Arkansas. Registered protestant and sys-

\footnotetext{
Received for publication 22 Mar. 1993. Accepted for publication 7 July 1993. Research conducted at Christy Woods, Muncie, Ind., and the Univ. of Arkansas Agricultural Experiment Station Farm, Fayetteville. We thank Jen Carr for typing this manuscript. The cost of publishing this paper was defrayed in part by the payment of page charges. Under postal regulations, this paper therefore must be hereby marked advertisement solely to indicate this fact.

Assistant Professor.

${ }^{2}$ Extension Horticulturist.
}

temic fungicides were applied, but the disease still approached epidemic proportions, with $60 \%$ disease incidence. Commercial production of interspecific hybrid grapes is expanding rapidly in this region of the United States. Cultivars developed by the Univ. of Arkansas Agricultural Experiment Station, including 'Venus' (Moore and Brown, 1977), 'Reliance' (Moore, 1983), 'Mars' (Moore, 1985), and 'Saturn' (Moore et al., 1989), all interspecific hybrids of $V$. labrusca $\times V$. vinifera, are being planted rapidly to contribute to further expansion of this industry. The large amount of $S$. ampelina inoculum in this area is of concern because no information is available on susceptibility of interspecific hybrid cultivars, especially those with $V$. labrusca heritage.

Objectives of this study were to determine if 1) interspecific hybrid cultivars of $V$. labrusca $V$. vinifera are susceptible to septoria leaf spot and 2) there is a correlation between percent $V$. labrusca ancestry of a particular cultivar and susceptibility to septoria leaf spot.

\section{Materials and Methods}

Pathogen isolation and culture. Two isolates of Septoria ampelina (89-602 and 91$537)$ were collected from diseased 'Concord' grape leaves in Washington Co., Ark. Conidia of $S$. ampelina were isolated from sporulating lesions by using a heat-sterilized dissecting needle under a stereomicroscope and then transferring the conidia to potato-lextrose agar (PDA). Isolates were maintained in glycerol-skim milk at $-80 \mathrm{C}$.

Conidial inoculum of isolates was produced on pea extract agar plates $(400 \mathrm{ml}$ of canning liquid from commercial, salt-free, canned peas, $18 \mathrm{~g}$ agar, and $600 \mathrm{ml}$ distilled water) seeded with conidia from 8- to 9-dayold cultures. Plates were incubated on a laboratory bench for 8 to 10 days at $26 \mathrm{C}$ under cool-white fluorescent lights (1: 1, GroLux) adjusted to a 14-h photoperiod.

Grape culture. Rooted grape cuttings were planted into 4-liter plastic pots (one plant/pot) containing 2 peat: 1 perlite: 1 vermiculite (by volume)mix amended with $6.3 \mathrm{~kg} \mathrm{CaCO}_{3}$ and $1 \mathrm{~kg}$ Osmocote $17 \mathrm{~N}-9 \mathrm{P}-13 \mathrm{~K}$ fertilizer per cubic meter. Plants were grown outside in a slatted-shadehouse until six fully expanded true leaves were present.

Grape cultivars tested included: Vitis aestivalis ('Cynthiana'), V. labrusca ('Concord', 'Fredonia', and 'Niagara'), V. rotundifolia ('Cowart' and 'Fry'), V. vinifera ('Cabernet Sauvignon', 'Chardonnay', 'Flame Seedless', and 'Thompson Seedless'); and interspecific hybrids ('Einset Seedless', 'Mars', 'Reliance', 'Rivat', 'Saturn', 'Vanessa', and 'Venus' ). 'Rivat' is believed to be a hybrid of $V$. rupestris $\times V$. vinifera, while the remainder of interspecific hybrid cultivars tested are progeny from crosses of $V$. labrusca $\times V$. vinifera.

Pathogenicity tests. Each treatment consisted of two grape plants, and the experiment was replicated twice. An aqueous conidial suspension of each fungal isolate (89-602 and 91-537), amendedwith Tween $20(0.02 \%, \mathrm{v} / \mathrm{v})$, was prepared and standardized at $1 \times 10^{6}$ spores/ml with a hemacytometer. The two isolates were then mixed $1: 1$. The third and fourth true leaves of the plants were inoculated to runoff with the conidial suspension using an artist's airbrush atomizer $\left(1.37 \times 10^{5} \mathrm{~Pa}\right)$. Leaves of controls (two plants of each cultivar) were sprayed with water plus surfactant only. Sprayed plants were air-dried, placed into a dew-deposition chamber at $24 \mathrm{C}$ for $20 \mathrm{~h}$, returned to the shadehouse, and arranged in a randomizedcomplete-blockdesign.Theshadehouse area was equipped with overhead sprinkler irrigation adjusted to run for $4 \mathrm{~min}$ at 0800, 1000, and $2000 \mathrm{~m}$ daily. This regime was followed for 7 days after inoculation, then the sprinkler was adjusted to run once a day at $1000_{\text {HR }}$ for 4 min until the end of the experiment. All plants were examined twice a week for 4 weeks for disease symptoms and rated as immune if no symptoms were found and susceptible if lesions were found. After 28 days, plants were rated for disease severity as follows: $0=$ no disease; $1=1 \%$ to $10 \%$ of leaf tissue with lesions; $2=11 \%$ to $25 \%$ of leaf tissue with lesions; $3=26 \%$ to50\%leaf tissue with lesions, $1 \%$ to $10 \%$ necrotic tissue; $4=$ $51 \%$ to $75 \%$ leaf tissue with lesions, $25 \%$ to $50 \%$ necrotic tissue; $5=76 \%$ to $90 \%$ leaf tissue covered with lesions, $51 \%$ to $80 \%$ necrotic tissue; and $6=$ dead or abscised leaves.

After final ratings were obtained, inoculated leaves were removed from plants, placed into moist chambers for 4 days, and observed for sporulation. Conidial masses, if present, were observed under the microscope to verify the presence of Septoria spores.

Percentage of $V$. labrusca ancestry in selected interspecific hybrid cultivars, in conjunction with disease seventy data from se- 
lected cultivars, was plotted to determine if a correlation exists between percent $V$. labrusca of a clone and susceptibility to septona leaf spot. Vitis vinifera grape cultivars analyzed in this manner included 'Chardonnay', 'Thompson Seedless', 'Flame Seedless', and 'Cabernet Sauvignon', which are assumed to be $100 \% \mathrm{~V}$. vinifera. American grape cultivars analyzed included 'Fredonia', 'Concord', and 'Niagara', which are assumed to be $100 \% \mathrm{~V}$. labrusca.

A nested analysis of variance (ANOVA) was run on disease severity data using the MANOVA procedure of SPSS (SPSS Inc., 1988). The LSD post-hoc tests were run using the one-way procedure of SPSS. The denominator for the overall test was modified according to the hierarchical design analyzed under MANOVA.

\section{Results and Discussion}

Septoria ampelina caused leaf spot lesions in all grape cultivars tested. 'Chardonnay', 'Cynthi-ana', 'Einset Seedless', 'Flame Seedless', 'Rivat', 'Thompson Seedless', and 'Vanessa' developed leaf spot symptoms 8 days after inoculation. Symptoms of leaf spot appeared in 'Cabernet Sauvignon', 'Cowart', 'Fry', 'Mars', 'Reliance', and 'Saturn' 13 days after inoculation. Lesions on 'Cowart' and 'Fry' were water-soaked and appeared to be a hypersensitive-type response to infection. Leaf spot symptoms did not appear in the remaining two cultivars tested, 'Concord' and 'Fredonia', until 18 days after inoculation. Sporulation of the fungus was observed in all inoculated leaf samples placed into humidity chambers, except in 'Cowart' and 'Fry'. From the 17 cultivars tested representing five distinct grape species and interspecific hybrids, 'Cowart' and 'Fry' (both $V$. rotundifolia) were the only cultivars that appeared resistant to this fungus.

According to disease seventy ratings of the grape cultivars, the $V$. vinifera cultivar Cabernet Sauvignon was highly susceptible to this fungus (Table 1). About 37\% defoliation occurred by experiment termination. In general, the widely planted $V$. vinfera cultivars were significantly more susceptible to $S$. ampelina than American cultivars. These data contradict earlier reports that $V$. vinifera cultivars are immune to this disease and only American Vitis spp. are susceptible (Boubals and Mur, 1983; McGrew and Pollack, 1988). In fact, the American cultivars Fredonia, Concord, and Niagara exhibited the highest resistance to this fungus (Table 1). The only highly susceptible America cultivar was 'Cynthiana' ( $V$. aestivalis). Susceptibility in hybrid cultivars ranged from high ('Saturn' and 'Vanessa'), to moderate ( 'Einset Seedless', 'Reliance', and 'Rivat'), to low ('Venus' and 'Mars') in disease severity. This was expected in hybrids of American $x$ European grapes, where varying levels of American (e.g., V. labrusca) heritage
Table 1. Susceptibility of selected grape cultivars to the fungus Septoria ampelina.

\begin{tabular}{llc}
\hline \hline Cultivar & $\begin{array}{c}\text { Mean disease } \\
\text { rating }\end{array}$ & $\begin{array}{c}\text { Species }^{z} \\
\text { ancestry }^{\mathrm{y}}\end{array}$ \\
\hline Fredonia & $1.13 \mathrm{a}^{\mathrm{x}}$ & $\mathrm{A}$ \\
Concord & $1.38 \mathrm{ab}$ & $\mathrm{A}$ \\
Niagara & $1.75 \mathrm{a}-\mathrm{c}$ & $\mathrm{A}$ \\
Fry & $1.25 \mathrm{a}$ & $\mathrm{A}$ \\
Cowart & $2.38 \mathrm{~cd}$ & $\mathrm{~A}$ \\
Cynthiana & $3.88 \mathrm{f}$ & $\mathrm{A}$ \\
Venus & $1.63 \mathrm{a}-\mathrm{c}$ & $\mathrm{IH}$ \\
Mars & $2.13 \mathrm{~b}-\mathrm{d}$ & $\mathrm{IH}$ \\
Einset Seedless & $3.25 \mathrm{ef}$ & $\mathrm{IH}$ \\
Reliance & $3.25 \mathrm{ef}$ & $\mathrm{IH}$ \\
Saturn & $3.50 \mathrm{f}$ & $\mathrm{IH}$ \\
Vanessa & $3.88 \mathrm{f}$ & $\mathrm{IH}$ \\
Rivat & $2.75 \mathrm{de}$ & $\mathrm{IH}$ \\
Chardonnay & $3.38 \mathrm{ef}$ & $\mathrm{E}$ \\
Thompson Seedless & $3.38 \mathrm{ef}$ & $\mathrm{E}$ \\
Flame Seedless & $4.00 \mathrm{f}$ & $\mathrm{E}$ \\
Cabernet Sauvignon & $5.38 \mathrm{~g}$ & $\mathrm{E}$ \\
\hline
\end{tabular}

${ }^{\mathrm{z}} \mathrm{A}=$ American or native, $\mathrm{IH}=$ interspecific hybrid, $\mathrm{E}=$ European grapes.

'Disease severity ratings: $0=$ no disease; $1=1 \%$ to $10 \%$ of leaf tissue with lesions; $2=11 \%$ to $25 \%$ of leaf tissue with lesions; $3=26 \%$ to $50 \%$ leaf tissue with lesions, $1 \%$ to $10 \%$ necrotic tissue; $4=51 \%$ to $75 \%$ leaf tissue with lesions, $25 \%$ to $50 \%$ necrosis; $5=76 \%$ to $90 \%$ leaf tissue covered with lesions, $51 \%$ to $80 \%$ necrosis; and $6=$ dead or abscised leaves.

${ }^{x}$ Mean separation in the column by LSD $(P \leq 0.05)$.

Table 2. Ancestry of selected interspecific hybrid grape cultivars.

\begin{tabular}{lcc}
\hline \hline Cultivar & V. vinifera ${ }^{2}(\%)$ & V. labrusca $(\%)$ \\
\hline Reliance & 25 & 75 \\
Mars & 40 & 60 \\
Venus & 60 & 40 \\
Saturn & 78 & 22
\end{tabular}

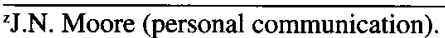

could result in offspring from a particular cross.

The percentage of $V$. labrusca ancestry in several selected interspecific hybrid cultivars (Table 2), in conjunction with disease severity data from selected cultivars (Table 1), was plotted to determine if a correlation exists between percentage of $V$. labrusca in a clone and susceptibility to septoria leaf spot. The correlation coefficient $(r)$ was high $(-0.80)$, suggesting that there is a correlation between percentage of $V$. labrusca in ancestry and susceptibility to $S$. ampelina in the cultivars tested (Fig. 1). Validation resulted in a linear equation, with intercept 3.90 and a slope of -0.024 .

The $r$ value could be higher than current data demonstrate. Susceptibility to septoria leaf spot disease in V. labrusca may not always be transferred to the same degree, or even at all, in specific crosses made of $V$. labrusca $\times V$. vinifera. . Indeed, if this occurred in the selection of 'Reliance' and 'Venus' (Fig. 1), removal of these two data points from

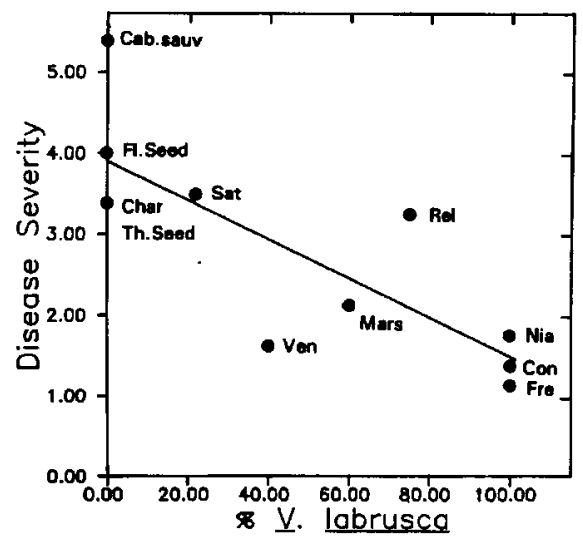

Fig. 1. Comparison of percent $V$. labrusca heritage in selected grape cultivars with susceptibility to septoria leaf spot. $\mathrm{Y}=-0.024 \mathrm{X}+3.9, r=-0.80$.

the correlation analysis would increase the $r$ value to -0.90 (intercept 4.02 , slope of -0.027 ). In addition, the inclusion of disease severity data from more hybrids could potentially change the value of $r$. We were able to collect information on only the percentage of $V$. labrusca ancestry for the four hybrids included in this experiment.

Cultivars are being evaluated, selected, and released in several Vitis breeding programs to improve quality at present. Results of this study suggest that septoria leaf spot is a potentially devastating disease of European and interspecific hybrid grape cultivars. New plantings in grape-producing areas that have a high potential for septoria leaf spot should consist of American Vitis spp. or hybrid cultivars containing a high percentage of $V$. labrusca heritage. Information is needed on environmental parameters necessary for infection of grapes by $S$. ampelina and sensitivity of this fungus to currently registered fungicides.

\section{Literature Cited}

Boubals, D. and G. Mur. 1983. Another grapevine disease is raging in Penedes(Spain)(in Russian withEnglishabstr.).Prog.Agr.Viticult.100:453.

McGrew, J.R. and F.G. Pollack. 1988. Septoria leaf spot, p. 31. In: R.C. Pearson and A.C. Goheen (eds.). Compendium of grape diseases. Amer. Phytopathol. Sot. Press, St. Paul, Minn.

Moore, J.N. 1983. 'Reliance' seedless grape. HortScience 18:963-964.

Moore, J.N. 1985. 'Mars' seedless grape. HortScience 20:313.

Moore, J.N. and E. Brown. 1977. 'Venus' grape. HortScience 12:585.

Moore,J.N., J.R. Clark, and J.R. Morns. 1989. 'Saturn'seedless grape.HortScience 24: 861-862.

SPSS, Inc. 1988. SPSS reference guide.4thed. Stat. Package for the Social Sciences Inc., Chicago.

Teterevnikova-Babayan, D.N. 1977. On the pathogensofseptoriadiseaseof grpaevine(in Russian with English abstr.).Biol.Zhur.Armenii30:1317. 